\title{
Teachers' cloud-based learning designs: The development of a guiding rubric using the
}

\section{TPACK framework}

\section{Abstract}

This study aimed to develop, validate and trial a rubric for evaluating the cloud-based learning designs (CBLD) that were developed by teachers using virtual learning environments. The rubric was developed using the technological pedagogical content knowledge (TPACK) framework, with rubric development including content and expert validation of its items and levels. The rubric was revised based on various types of input including content validity and expert review. After many iterations of rubric implementation using two raters, the final version of the rubric was found to be reliable with high and substantial inter-rater reliability. This study provides a methodological contribution by developing and validating a rubric for teachers' cloud-based learning designs. It also provides a useful tool for evaluating the quality of teachers' CBLD, and assessing training needs.

Keywords: TPACK, cloud, learning designs, rubric, virtual learning environments (VLE), K-12 teachers, K-12 online education

\section{Introduction}

One new and emerging technology is cloud-based computing (Wang, Rasid, \& Chuang, 2011) which can be referred as an "expandable, on demand service” (Johnson, Adams Becker, Estrada \& Freeman, 2014, p. 36). This also includes tools that are accessed by the user via the internet from specialized data centers. As the use of cloud-based computing technology in schools globally shows increasing potential benefits (Hartmann, Braae, Pedersen, \& Khalid, 2016) and more teachers use this technology to generate learning resources, our development of a rubric to evaluate quality of designed learning content becomes even more valuable. 
Technologies are constantly changing with teachers needing to change the technologies they use due to this (Johnson et al., 2014). Thus, this study will focus on teachers preparing and using content on the cloud in both primary and secondary schools. This paper adds to the literature in a timely manner as it can assist others to evaluate their new learning design content.

This study used the TPACK framework as it is a way of representing what teachers know about technology (Koehler \& Mishra, 2005). This framework, developed by Mishra and Koehler (2006), “emphasizes the connections, interactions, affordances, and constraints between and among content, pedagogy, and technology” (p. 1025), indicating that these components (see Figure 1) can be viewed in pairs at the intersected points on the diagram. The components of TPACK are:

- pedagogical content knowledge (PCK),

- technological content knowledge (TCK),

- technological pedagogical knowledge (TPK).

With the point where all three circles intersect being technological pedagogical and content knowledge (TPACK), as shown in Figure 1.

[Insert Figure 1 here]

When reviewing the literature relevant to TPACK, it can be seen that learning through design and the engagement of teachers about the relationships amongst the technology, content and pedagogy were central to courses in which the development of TPACK has been demonstrated (Graham et al., 2009; Koehler, 2012). As new technologies are constantly being developed, traditional approaches to the design and the delivery of learning interventions is being challenged by both academics and teachers alike, as they may not meet the needs and expectations of modern learners. New pedagogies and technologies seem to offer promise in creating exciting educational experiences for the learner (Conole, 2010). 
The TPACK framework, developed by Mishra and Koehler (Koehler \& Mishra, 2005; Mishra \& Koehler, 2006) builds on Shulman’s (1986, 1987) descriptions of pedagogical content knowledge and describes how teachers' understanding of technology along with content and pedagogical knowledge are integrated into their teaching. Koehler and Mishra suggest that good teaching is not simply adding the use of technology to existing teaching and content but rather it is the "representation of new concepts and requires developing a sensitivity to the dynamic, transactional relationship between all three components suggested by the TPCK framework” (Koehler \& Mishra, 2005, p. 134).

\section{Learning Design}

Although researchers have developed several definitions of learning design, one definition refers to the variety of ways that student learning experiences can be designed, specifically online learning experiences from designing learning activities to developing software tools and systems (Garzotto \& Retalis, 2009). Importantly, learning design can be described as a 'framework' to make explicit the conceptual and practical underpinnings that form a sequence of educational type activities in an online environment (Dalziel 2008). This framework supports student learning experiences ("Learning Design: The Learning Design Construct," 2003), including those online, with Oliver (1999) suggesting a learning design can be comprised of three key elements. These are the tasks the learner is required to do, the resources that support learners to complete the task and the support mechanisms that exist from the teacher implementing it. Learning design research has occurred in response to a perceived gap between the potential of technologies in terms of their use to support learning and their actual use in practice (Bennett et al., 2007; Conole, Dyke, Oliver, \& Seale, 2004).

In detail, learning design patterns should embody “educational values and vision” (Goodyear 2005, p. 82). These patterns can provide a reproducible and sharable template that can be represented in several ways, including graphically, textually, or in codable, machine- 
readable form. There is an IMS Learning Design that can be thought of as a product that is a framework that supports diversity within pedagogies and promotes innovation (IMS Global Learning Consortium, 2003). Learning design research has built on this initial framework as it is an "attempt to bring a fuller picture to electronic exchange that can theoretically include all forms of highly complex and flexible learning for both online and face-to-face learning venues” (Berggren et al., 2005, p. 2).

\section{Cloud-based computing}

As cloud computing has assisted in empowering the shift from personal to interpersonal computing this means the significance (Erl, Puttini, \& Mahmmod, 2013) can be viewed as more social than technological. Digital content and media that was once stored on individual teachers' and students' computers and suffered from sharing and accessibility limitations has now become available anytime, anywhere and on almost any device through a series of networked servers. Cloud computing has enabled more accessible, scalable and yet flexible on demand learning (Fernandez et al., 2012), where more and more learning is happening on the cloud and not on personal computing devices. This shift has impacted many aspects of education such as communities of educators and learners, and has allowed access to low-cost content, and creation and delivery of content through Virtual Learning Environments (VLEs) (Bughin, Chui, \& Manyika, 2010). In addition to providing a solid infrastructure for the network, platform, and professional development services for users at different levels, a huge volume of learning material and digital content resources must constantly be supplied and managed. Ideally, these learning resources, delivered through the web and other internet enabled networks, should be scalable, sharable, relevant, contextualized and collaborative in nature (Dholakia, King, \& Baraniuk, 2006).

The concept of digital content in education has had a number of incarnations, dating back to the arrival of the first e-books in the market in 1971, through to multimedia enriched 
resources with the aim of engaging students with various learning preferences, for example, interactive online environments such as khanacademy.org (Thompson, 2011). Across various formats and types of digital content, topics such as development and sharing, relevance, accessibility and affordability recur in the literature. Furthermore, several content models have been designed, deployed and revised to best fulfill the needs of today's learners. For the purpose of this investigation, digital content using cloud computing has been defined as pedagogical material that has been accessed and used in schools in its digital (electronic) form.

\section{Methodology and Results}

The literature reveals a number of studies that developed a rubric to assess TPACK in the learning activities designed by teachers to integrate information and communication technology. Our focus in this study falls within what Koehler, Mishra, Kereluik, Shin, and Graham (2014) refer to as performance assessments studies of TPACK. These studies measure teachers' created content such as lesson plans. As Harris, Grandgenett, and Hofer (2010) explain, through this way of assessment researchers can discern teachers' TPACK knowledge by assessing their real practices in a more systematic and reliable way with a rubric representing TPACK segments on different design and learning dimensions. For example, Koh (2013), based her rubric on the five dimensions of meaningful learning, which are active, constructive, authentic, intentional, and cooperative learning. Lessons produced by student-teachers were classified based on this rubric on five levels for each of these dimensions. Harris, Grandgenett, and Hofer (2010) adapted the Technology Integration Assessment Instrument (TIAI) developed by Britten and Cassady’s (2005) to reflect TPACK in four dimensions: curriculum goals and technologies, instructional strategies and technologies, technology selection and fit. It evaluated preservice teachers' lessons on four levels in these four dimensions. This adapted rubric was later used by Hofer and Grandgenett (2012) to document the growth of TPACK during the course of a teacher education program through scoring student lessons on it. 
This study is different from the previous literature in two ways. Firstly, it specifically focuses on designing learning activities using cloud-created content while previous studies tend to have a broader focus on designing learning activities using information and communication technology. Secondly, previous studies generally evaluate content created by preservice teachers who may have been exposed to an intervention by being taught TPACK in their teacher education courses, however, this study is measuring content produced by actual teachers regardless of their TPACK knowledge. The research process to develop the rubric for evaluating the teacher created cloud-based learning designs (CBLD) included four phases (see Figure 2). These phases, involved collecting and analyzing both quantitative and qualitative data to address the different concerns of the validity and reliability of the rubric content and scores collected using it.

\section{[Insert Figure 2 here]}

\section{Samples of Teachers' Cloud Based Learning Designs (CBLD)}

The samples of teacher created CBLD were randomly selected from the CBLD created in the 1BestariNet project, which is an initiative led by the Malaysian Ministry of Education as part of the Malaysian Education Blueprint 2013-2025 (Malaysian Ministry of Education, 2013). Through this project, the Malaysian government equipped over 10,000 primary and secondary government schools nationwide with 4G internet connectivity and a cloud-based Virtual Learning Environment which is called Frog VLE. Using this environment, teachers can freely create their own CBLD to use in their classrooms and they can also share with other teachers, if they chose to do so.

\section{Phase I}

In the first phase of the rubric development, the current literature on the TPACK framework and the special characteristics of cloud-based learning designs were reviewed to establish content validity. Using this literature, the focus of the rubric was defined to be on the 
TPACK intersection as well as the Technology-Pedagogy-Knowledge (TPK), the TechnologyContent-Knowledge (TCK) and the Technology-Knowledge (TK). This choice is justified on the basis that this rubric focuses on learning designs that are only cloud-based. Therefore, it does not evaluate other TPACK sections related to teachers' content and pedagogical knowledge Content-Knowledge (CK), Pedagogy-Knowledge (PK), and Pedagogy-Content Knowledge (PCK).

Rubric content validity suggests that the rubric measures what it is supposed to measure (Colman, 2015). This is established through many ways, including examining the rubric items to make sure they cover all the relevant items. Another measure is to ask other researchers to evaluate items and their sub-content (Lodico, Spaulding, \& Voegtle, 2010). In the development of this rubric, we made sure that each TPACK item is represented at least once, with many of them overlapping. Therefore, expert validation of the rubric was elicited and we asked about the relevancy of the rubric items to the TPACK framework. The first version of the rubric included twelve items relating to the learning designs. These were purpose and objectives, instructions and guidelines, interaction, learning styles, use of media and tools, links and resources, active learning, engagement tools, text visual engagement, visual consistency, visual appeal, and navigation flow. Alignment of CBLD with the TPACK framework was assessed on each of these items based on four levels. Level 1 indicated "unsatisfactory" alignment of the CBLD. Level 2 indicated "developing" alignment of the CBLD. Level 3 indicated "acceptable" alignment of the CBLD, and level 4 means it has "optimal" alignment.

\section{Phase II}

Rubric use is affected by the rater's using it, as they can vary and be more lenient or strict. Some raters may be affected by their knowledge of the people being evaluated, which is called a halo effect. Some have a tendency to give an average score. Some raters are idiosyncratic, and some are not logical. These variations in rating can lead to systematic errors by the raters, 
and therefore reduce the reliability of the scores collected using the rubric. Training raters on how to use the rubric is one way to improve scores consistency (Haladyna \& Rodriguez, 2013). In this phase of the research, two raters were trained on using the rubric to evaluate CBLD.

A random sample of 31 CBLD were chosen for the evaluation. One of the raters did not complete the evaluation of all 31 CBLD, so two of the researchers conducted the evaluation of the designs. A total of three raters evaluated the chosen 31 CBLD. All raters had experience with cloud-content development and the cloud-based Virtual Learning Environment (Frog VLE). Kohen’s Kappa and Intraclass Correlation Coefficient (ICC) were used to measure for inter-rater reliability. In addition, Cronbach’s alpha was used to test for the rubric internal consistency as whole scale.

\section{Inter-rater Reliability}

This study used Cohen's Kappa to test for the inter-rater reliability to test for the agreement between raters, and to test if the observed agreement is greater than agreement by chance (Stemler \& Tsai, 2008). Interpretation of Cohen’s Kappa is based on Landis and Koch (1977), with values between .21 to .40 indicating fair agreement, values between.41 to .60 indicating moderate agreement, and values between .61 to .80 indicating substantial agreement (see Table 1). The overall average of Cohen Kappa in the study indicated a moderate agreement between all raters. The inter-rater reliability between each pair of raters indicates mostly significant ( $p$ value of .001) Cohen kappa values. At this stage, there were more agreements between the first and third raters and the second and third raters, with the least agreement between the first and second rater. These differences reflected the different backgrounds of the three raters and their level of familiarity with the VLE platform. The first and third raters had more familiarity with the VLE platform than the second rater, while the second and third raters had more academic and work experience than the first rater. 


\section{[Insert Table 1 here]}

\section{Intraclass Correlation Coefficient (ICC)}

The intraclass Correlation (ICC) coefficient was also used to test for raters' reliability. ICC has the advantage of accounting for both the consensus (mean difference) between raters and consistency (association). It uses different raters’ reliability data of their rating (Stemler \& Tsai, 2008). The ICC between the three raters was calculated for each component in the rubric as well as the total score, which is the sum score of all rubric components for each rater (Table 2). As the table shows, ICC varied between .895 and .682, and the total score ICC was .937 . This high ICC value indicates an average of 93\% agreement between the three raters. Navigation flow had the lowest ICC value indicating only 68\% agreement between the raters. Clearly there is a problem in interpreting the rubric levels for this item, as the lower band 95\% confidence interval is .42. Notes from raters explained the confusion of navigation flow, especially in learning designs that included only one tab. In addition, at times, for some raters, navigation flow seemed to be a part of the platform structure rather than a logical choice that teachers have to make.

\section{[Insert Table 2 here]}

\section{Internal Consistency}

To test for internal consistency, Cronbach's Alpha was used. This was above 0.9 for each of the three raters. This indicates excellent reliability of the rubric, meaning that all rubric components seem to measure for the same dimension of design alignment with the TPACK framework. Based on the results and feedback from the first implementation of the rubric, the researchers made more modifications to the rubric. These include adding a new item, namely "functionality", which appeared to be an issue when evaluating the CBLD as some items like videos or images did not load properly. Three items (text visual engagement, visual consistency and visual appeal) were collapsed into a new item, namely “visual consistency”. 


\section{Phase III}

Expert validation was used to evaluate the second version of the rubric. The use of expert panels offers a deeper and broader perspective on specialized issues (Johnson, 2015), for example, the creation of this rubric. Rubric items were validated through an online questionnaire based on language clarity, relevance to TPACK, distinctiveness of the item rating levels, and importance for cloud-based designs. In addition, experts were invited to provide qualitative comments to specify the issues with rubric items and suggest ways to resolve them. Purposive sampling of experts (Hartas, 2015) was used and by targeting educational designers, instructional technologists and university professors specialized in instructional design, we gained a variety of experts who volunteered their time. The quality of experts and their qualifications is more important than their number because this is a purposive sample (Powell, 2003).

In this study, 24 experts were invited to participate, but the final expert sample consisted of 13 experts, who came from five universities in Australia, Malaysia and Oman. More than half of them had a doctoral degree in educational design and all had a master's degree. Seven experts indicated they were familiar with TPACK, five indicated they were somewhat familiar with TPACK, and only one indicated lack of familiarity with TPACK. Further analysis of this person indicated rich responses and familiarity with cloud-based designs, the reason which we decided to keep the responses from this person. Table 3 summarizes the aggregation of expert responses on the rubric items per each evaluation criterion.

\section{[Insert Table 3 here]}

The purpose of the expert validation was to improve the second version of the rubric. Achieving consensus in expert validation is arbitrary and the literature varies in the acceptable percentage of consensus because of the variation of such studies in scope and purpose (Powell, 2003). Therefore, we incorporated the experts' feedback to improve all rubric items. We 
focused on items that had less than $70 \%$ of expert agreement. As indicated in Table 3, experts found all rubric items to be mostly clear, relevant, distinctive and important. Less than $70 \%$ of the experts rated two items as clear and two other items as relevant to TPACK. Qualitative analysis of experts' feedback was used to focus on these four items. They suggested simplifying the language used in the rubric and clarifying the levels of the rubric to make it easier to distinguish between them.

In addition, experts suggested the use of current educational terminologies and literature. Based on this, "purpose and objectives” was changed to "learning outcomes" and “learning styles” was changed to "learning preferences”. Other modifications were made to the rubric to assure consistency of the levels of all items, so item at the top level "optimal” will include multiple, many examples of the criterion items throughout the design, while items at the lower level "unsatisfactory" will include none of the criterion items. Items that are “acceptable” will include some examples of the criterion items and items that are "developing” will include a few or limited examples of the criterion items. This quantitative distinction between the levels is used to support the qualitative description of each level. This expert validation process ended with the third version of the rubric.

\section{Phase IIII}

In this stage, the third version of the rubric was validated using a new round of inter-rater reliability analysis. Training was offered to two raters on the rubric and its rating levels. The training sessions aimed to ensure a common understanding between the two raters on the rubric items and rating levels. Then, the two raters independently evaluated 46 designs using the rubric. Scores were compared to verify the estimated inter-rater reliability between them. Table

2 reports Cohen's Kappa inter-rater reliability coefficients. The Kappa coefficient for "Functionality" was the only one that indicated moderate agreement. 
Cohen’s Kappa coefficients for six elements in the rubric indicated fair agreement, and for three other elements it was less than .2 indicating slight agreement. This lack of inter-rater reliability made us question the clarity of the rubric items, compelling us to review the rubric once again. In order to do so, qualitative feedback from the raters about the rubric items, descriptions and levels was utilized. This modification included adding more consistency to the rubric description of the levels in the final version (version 4, see Appendix A).

\section{Phase V}

Raters were debriefed about the modifications on the rubric. They were also given some explanation on the elements and levels. Then, the two raters independently evaluated 144 sites using the rubric. Scores comparisons showed that there was still an issue with the inter-rater reliability. With the exception of the coefficients for "Learning Outcomes" and "Learning Preferences”, the rest of Cohen's Kappa coefficients indicated less than moderate inter-rater agreement $(>0.4)$. Some have digressed even more when compared with the initial inter-rater agreement. To understand the areas of differences both the raters and researchers engaged in lengthily discussion, sampling and evaluating designs together.

Results from this process indicated that there were some differences between the raters in their understanding of the rubric. This was because while one focused more on the quantity, the other rater focused more on the quality. They also had difficulty to apply the criteria for the items of subjective nature such as relevance and suitability of tools, links and resources to learning outcomes. It was easier to measure items that specified a number referring to the frequency an item is used in a learning design. Another issue was their different interpretations of what translates as “some”, a "few" or "most”. Therefore, to create a common ground, both the researchers and raters collaboratively wrote a guideline for the rubric, which clearly states when an item should be score 1, 2, 3 or 4 . It also specified the extensiveness of the criteria availability by percentages, as they are easier to interpret rather than words. Using this detailed 
guideline, the raters evaluated 31 designs. Cohen Kappa coefficients did not improve much after this effort.

\section{Phase VI}

The differences between the two raters in their personalities and experiences lead to a big variation in their rating of the learning designs despite the detailed guideline for the rubric. This required a different approach to create consensus between them by asking them to rate designs together and negotiate scores for each design to eventually agree on a single score. This process was conducted for the first 100 designs with the highest score disparity. After that, each rater independently rated 53 new designs. Results of the inter-rater reliability of these designs clearly indicated high reliability between the two raters with seven rubric items with substantial agreement and three items with moderate agreement, as presented in Table 4.

\section{[Insert Table 4 here]}

Additionally, this final rubric was piloted to evaluate 152 new cloud-based learning designs created by school teachers. The results from this pilot showed that CBLD were only optimally aligned with the TPACK framework in three areas, the use of links, navigation flow and functionality, while the least alignment was in interactivity (Campbell, Al-Harthi, \& Karimi, 2015).

\section{Rubric Trial}

The purpose of this rubric was to identify the alignment level of teacher-created cloud-based learning designs (CBLD) with TPACK framework. Results from this alignment will help to improve the designs quality by addressing the areas with lower levels of alignment. Therefore, following the previously mentioned pilot application, we evaluated 583 new CBLD using the final version of the rubric. These CBLD were created by Malaysian teachers in the same virtual learning environment (VLE), and were scored by the two trained raters 
who participated in the rubric development. These designs covered various content areas including math, sciences, languages and extracurricular areas. For his data (N=583 CBLD), the rubric was found to be reliable with a Cronbach’s Alpha coefficient of .790, indicating an acceptable reliability (George \& Mallery, 2003). Next, we tested the level of alignment of the teachers' learning designs with the TPACK framework. Table 5 shows the criteria used to interpret the scores. Based on the criteria, four rubric items (the use of links, design visual consistency, design navigation flow and design functionality) were found to be optimally aligned with the TPACK framework across the 583 learning designs. Only "interactivity" was found to have developing or emerging alignment with the TPACK framework. The rest of the rubric items were found to have acceptable alignment with the TPACK framework.

\section{[Insert Table 5 here]}

\section{Discussion and Conclusion}

The purpose of this study was to develop and then validate a rubric for evaluating teacher created cloud content, and to test for its use in evaluating learning designs developed by teachers. This process involved several phases to both test and then redesign the evaluation rubric. The rubric was modified during this testing phase to ensure its consistency and clarity. This study, thus provides a methodological contribution by developing and validating a rubric that can be used with cloud-based learning designs (CBLD) in virtual learning environments (VLEs). This process went through many phases of validation including content, expert and field validation using multiple methods to assure that the final rubric was scrutinized for every component to be a reliable measure for what it sets to measure.

Additionally, the rubric was trialed on a large number of teacher designs to evaluate the different CBLD elements against the technological, pedagogical, and content knowledge (TPACK). The trial application of the rubric indicated that teachers do not possess all TPACK 
at the same level. Their designs had an acceptable level of alignment with technological aspects more than the pedagogical aspects. In other words, while it might have been easier for teachers to curate cloud-created content and use the embedded features in the VLE environment, it is clear from the results that teachers need more education and training to skillfully designing cloud sites with optimal use of learning outcomes, instructions and guidelines, interactivity, engagement, learning preferences, as well as tools and media. Although we believe that all three types of knowledge are needed when designing for each element in the rubric, these areas require the start of a strong pedagogical and content knowledge. Furthermore, in the unique VLE context teachers need to use their technological knowledge in critical ways. After training, it would be easy for teachers to check their knowledge using the rubric in the future.

In addition to its methodological contribution, the available rubric is practically useful in evaluating the quality of teachers' CBLD and providing teacher training. Teachers can selfevaluate and improve their designs in different components of the rubric. At a higher level, educational systems using CBLD can also use the rubric to detect areas of weaknesses in TPACK and the contextual factors surrounding its use. Based on such analysis they can provide suitable teacher professional training according to the teachers' needs and resolve any institutional factors that may affect teacher integration of the cloud-based content. Thus, this rubric can impact instruction in a positive way to address weaknesses in TPACK learning design.

Through our experience in this study, training of rubric users is needed to enhance its use, as CBLD is still a developing area and when used in education there are contextual and pedagogical aspects that confound with its use. Koh, Chai, and Tay (2014) found that institutional factors dominate teachers' discussions, even more so than the TPACK factors, when adopting information and communication technology in an elementary school in Singapore which implemented innovative pedagogies. Therefore, resolving logistic issues 
related to CBLD use in schools needs to be addressed before or along with improving teachers' TPACK.

\section{References}

Bennett, S., Agostinho, S., Lockyer, L., Kosta, L., Jones, J., Koper, R., \& Harper, B. (2007). Learning designs: Bridging the gap between theory and practice. Paper presented at the ICT: Providing choices for learners and learning. Proceedings ascilite Singapore 2007, Singapore.

Berggren, A., Burgos, D., Fontana, J. M., Hinkelman, D., Hung, V., Hursh, A., \& Tielemans, G. (2005). Practical and pedagogical issues for teacher adoption of IMS Learning Design standards in Moodle LMS. Journal of Interactive Media in Education, 2, 1-24. Retrieved from http://jime.open.ac.uk/articles/10.5334/2005-2/

Britten, J. S., \& Cassady, J. C. (2005). The technology integration assessment instrument: Understanding planned use of technology by classroom teachers. Computers in the Schools, 22(3), 49-61. doi:10.1300/J025v22n03_05

Bughin, J., Chui, M., \& Manyika, J. (2010, August). Clouds, big data, and smart assets:. Ten tech-enabled business trends to watch. McKinsey Quarterly, pp. 1-14. Retrieved from http://www.mckinsey.com/insights/high_tech_telecoms_Internet/clouds_big_data_an d_smart_assets_ten_tech-enabled_business_trends_to_watch

Campbell, C., Al-Harthi, A., \& Karimi, A. (2015, November-December). Teachers’ cloudbased content creation in light of the TPACK framework: Implications for teacher education. In T. Reiners, B. R. von Konsky, D. Gibson, V. Chang, L. Irving, \& K. Clarke (Eds.), Globally connected, digitally enabled: Proceedings of ASCILITE 2015 (pp. CP:47-CP:51)., Perth, Australia. 
Colman, A. (2015). Content validity. In A dictionary of psychology. Oxford: Oxford University Press. Retrieved from http://www.oxfordreference.com/view/10.1093/acref/9780199657681.001.0001/ acref-9780199657681-e-1835

Conole, G. (2010). Learning design - Making practice explicit. Paper presented the ConnectEd 2010: 2nd International conference on Design Education, Sydney, Australia. Retrieved from http://cloudworks.ac.uk/cloud/view/4001

Conole, G., Dyke, M., Oliver, M., \& Seale, J. (2004). Mapping pedagogy and tools for effective learning design. Computers \& Education, 43(2004), 17-33. doi:10.1016/j.compedu.2003.12.018

Dalziel, J. (2008). Learning design: Sharing pedagogical know-how. In T. Iiyoshi \& M. S. V. Kumar (Eds.), Opening up education: The collective advancement of education through open technology, open content, and open knowledge. (pp. 375 - 387). Cambridge, Mass: MIT Press.

Dholakia, U., King, J., and Baraniuk, R. (2006). What makes an open education program sustainable? The case of connexions Retrieved from http://www.oecd.org/dataoecd/3/6/36781781.pdf

Erl, T., Puttini, R., \& Mahmood, Z. (2013). Cloud computing: Concepts, technology, \& architecture. Upper Saddle River, NJ: Prentice Hall. Retrieved from http://servicetechbooks.com/pdf/cloud_sample_chapter_1.pdf

Fernandez, A., Peralta, D., Herrera, F., \& Benítez, J. M. (2012, January). An overview of elearning in cloud computing. In Workshop on Learning Technology for Education in 
Cloud (LTEC'12) (pp. 35-46). Springer Berlin Heidelberg. doi: 10.1007/978-3-64230859-8_4

Garzotto, F. \& Retalis, S. (2009). A critical perspective on designing patterns for e-learning. In L. Lockyer, S. Bennett, S. Agostinho \& B. Harper (Eds.), Handbook of research on learning design and learning objects: Issues, applications and technologies. (pp.113143). Hershey, PA.: IGI Global.

George, D., \& Mallery, P. (2003). SPSS for Windows step by step: A simple guide and reference. (4th ed.). Boston: Allyn \& Bacon.

Goodyear, P. (2005). Educational design and networked learning: Patterns, pattern languages and design practice. Australian Journal of Educational Technology, 21(1), 82-101. doi: http://dx.doi.org/10.14742/ajet.v21i1.1344

Graham, C. R., Burgoyne, N., Cantrell, P., Smith, L., St Clair, L., \& Harris, R. (2009). TPACK development in science teaching: Measuring the TPACK confidence of inservice science teachers. TechTrends: For Leaders in Education \& Training, 53(5), 70-79. doi: 10.1007/s11528-009-0328-0

Haladyna, T. M. \& Rodriguez, M. C. (2013). Developing and validating test items. New York, NY: Routledge.

Harris, J., Grandgenett, N., \& Hofer, M. (2010). Testing a TPACK- based technology integration assessment rubric. In D. Gibson \& B. Dodge (Eds.), Proceedings of Society for Information Technology and Teacher Education International Conference 2010 (pp. 3833- 3840). Chesapeake, VA: AACE. 
Hartas, D. (2015). Quantitative research as a method of inquiry in education. In Hartas, D. (Ed.), Educational research and inquiry: Qualitative and quantitative approaches, (pp.65-81). London: Bloomsbury Publishing.

Hartmann, S. B., Braae, L. Q. N., Pedersen, S., \& Khalid, M. S. (2016). The potentials of using cloud computing in schools: A systematic literature review. Turkish Online Journal of Educational Technology, 16(1), 190-202. Retrieved from http://www.tojet.net/volumes/v16i1.pdf\#page=201

Hofer, M., \& Grandgenett, N. (2012). TPACK development in teacher education: A longitudinal study of preservice teachers in a secondary M.A.Ed. program. Journal of Research on Technology in Education, 45(1), 83-106.

doi: 10.1080/15391523.2012.10782598

IMS Global Learning Consortium. (2003). IMS Learning Design best practice and implementation guide. Retrieved from http://www.imsglobal.org/learningdesign/ldv1p0/imsld_bestv1p0.html

Johnson, G. (2015). Research methods for public administrators ( $3^{\text {rd }}$ ed.). New York: Routledge.

Johnson, L., Adams Becker, S., Estrada, V., and Freeman, A. (2014). NMC Horizon Report: 2014 K-12 Edition. Austin, Texas: The New Media Consortium. Retrieved from: http://www.nmc.org/publication/nmc-horizon-report-2014-k-12-edition/

Koehler, M. J. (2012). TPACK explained-The Seven Components of TPACK. Retrieved from http://matt-koehler.com/tpack2/tpack-explained/ 
Koehler, M. J., \& Mishra, P. (2005). What happens when teachers design educational technology? The development of technological pedagogical content knowledge. Journal of Educational Computing Research, 32(2), 131-152.

Koehler, M. J., \& Mishra, P. (2008). Introducing TPCK. In AACTE Committee on Innovation and Technology (Ed.), Handbook of Technological Pedagogical Content Knowledge (TPCK) for educators (pp. 3-29). New York: Routledge.

Koehler, M. J., Mishra P., Kereluik, K., Shin, T. S., Graham, C. R. (2014). The technological pedagogical content knowledge framework. $4^{\text {th }}$ Edition. In: J. M. Spector, M. D. Merrill, J. Elen, M. J. Bishop, (Eds.), Handbook of research on educational communications and technology, (pp. 101-111). New York, NY: Springer.

Koh, J. H. L. (2013). A rubric for assessing teachers' lesson activities with respect to TPACK for meaningful learning with ICT. Australasian Journal of Educational Technology, 29(6), 887-900.

Koh, J. H. L., Chai, C. S. \& Tay, L. Y. (2014). TPACK-in-action: Unpacking the contextual influences of teachers' construction of technological pedagogical content knowledge (TPACK). Computers \& Education, 78, 20-29. doi: 10.1016/j.compedu.2014.04.022

Landis, J. R., Koch, G. G. (1977). The measurement of observer agreement for categorical data. Biometrics, 33, 159-174. Retrieved from http://www.jstor.org/stable/2529310

Learning Design: The Learning Design Construct. (2003). Retrieved from http://www.learningdesigns.uow.edu.au/project/learn_design.htm

Lodico, M. G., Spaulding, D. T., \& Voegtle, K. H. (2010). Methods in educational research: From theory to practice. San Francisco, CA: Jossey-Bass. 
Ministry of Education. (2013). Malaysia Education Blueprint 2013 - 2025. Ministry of Education, Malaysia.

Mishra, P., \& Koehler, M. J. (2006). Technological pedagogical content knowledge: A framework for teacher knowledge. Teachers College Record, 108(6), 1017-1054. doi: 10.1111/j.1467-9620.2006.00684.x

Oliver, R. (1999). Exploring strategies for on-line teaching and learning. Distance Education, 20(2), 240 - 254. doi:10.1080/0158791990200205

Powell, C. (2003). The Delphi technique: Myths and realities. Journal of Advanced Nursing, 41(4), 376-382. doi:10.1046/j.1365-2648.2003.02537.x

Shulman, L. S. (1986). Those who understand: Knowledge growth in teaching. Educational Researcher, 15(2), 4-14. Retrieved from http://www.jstor.org/stable/1175860

Shulman, L. S. (1987). Knowledge and teaching: Foundations of the New Reform. Harvard Educational Review, 57(1), 1-22. doi: http://dx.doi.org/10.17763/haer.57.1.j463w79r56455411

Stemler, S., \& Tsai, J. (2008). Best practices in interrater reliability three common approaches. In J. Osborne (Ed.), Best practices in quantitative methods. (pp. 29-50). Thousand Oaks, CA: SAGE Publications, Inc.

Thompson, C. (2011). How Khan Academy is changing the rules of education. Wired Magazine, 126. Retrieved from http://resources.rosettastone.com/CDN/us/pdfs/K12/Wired_KhanAcademy.pdf

Wang, W. Y. C., Rashid, A., \& Chuang, H. (2011). Toward the trend of cloud computing. Journal of Electronic Commerce Research, 12(4), 238-242. 
Appendix A. Scoring Rubric for Evaluating the Alignment of Cloud-based Learning Designs (CBLD) Using the Technological Pedagogical and Content Knowledge (TPACK) Framework- (Final VersionVersion4)

\begin{tabular}{|c|c|c|c|c|}
\hline $\begin{array}{c}\text { CBLD } \\
\text { Components/ } \\
\text { Alignment } \\
\text { Levels }\end{array}$ & $\begin{array}{l}\text { Optimal } \\
\text { (4) }\end{array}$ & $\begin{array}{c}\text { Acceptable } \\
\text { (3) }\end{array}$ & $\begin{array}{l}\text { Developing } \\
\text { (2) }\end{array}$ & $\begin{array}{c}\text { Unsatisfactory } \\
\text { (1) }\end{array}$ \\
\hline $\begin{array}{l}\text { Learning } \\
\text { Outcomes } \\
\text { (PCK) }\end{array}$ & $\begin{array}{l}\text { The CBLD includes } \\
\text { and/or links to clear } \\
\text { and specific learning } \\
\text { outcomes. }\end{array}$ & $\begin{array}{l}\text { The CBLD includes } \\
\text { and/or links to clear } \\
\text { and specific learning } \\
\text { outcomes. }\end{array}$ & $\begin{array}{l}\text { The CBLD includes } \\
\text { and/or links to hardly } \\
\text { clear and specific } \\
\text { learning outcomes. }\end{array}$ & $\begin{array}{l}\text { The CBLD } \\
\text { includes and/or } \\
\text { links to no clear } \\
\text { or specific } \\
\text { learning } \\
\text { outcomes. }\end{array}$ \\
\hline $\begin{array}{l}\text { Instructions } \\
\text { and Guidelines }\end{array}$ & $\begin{array}{l}\text { The CBLD presents } \\
\text { and/or links to clear } \\
\text { and detailed } \\
\text { instructions and } \\
\text { guidelines about how } \\
\text { to interact with its } \\
\text { content and use it } \\
\text { throughout the } \\
\text { design. }\end{array}$ & $\begin{array}{l}\text { The CBLD presents } \\
\text { and/or links to clear } \\
\text { and detailed } \\
\text { instructions and } \\
\text { guidelines about how } \\
\text { to interact with its } \\
\text { content and use it in } \\
\text { most of the design. }\end{array}$ & $\begin{array}{l}\text { The CBLD presents } \\
\text { and/or links to clear } \\
\text { and detailed } \\
\text { instruction and } \\
\text { guidelines about how } \\
\text { to interact with its } \\
\text { content and use in } \\
\text { only a limited part of } \\
\text { the design. }\end{array}$ & $\begin{array}{l}\text { The CBLD } \\
\text { presents and/or } \\
\text { links no } \\
\text { instructions and } \\
\text { guidelines about } \\
\text { how to interact } \\
\text { with its content. }\end{array}$ \\
\hline Interactivity & $\begin{array}{l}\text { The CBLD includes } \\
\text { and/or links to } \\
\text { interactive activities } \\
\text { in which students } \\
\text { can edit or enter } \\
\text { data. All of these } \\
\text { activities are } \\
\text { logically sequenced } \\
\text { in the CBLD, and are } \\
\text { well linked to } \\
\text { learning outcomes. }\end{array}$ & $\begin{array}{l}\text { The CBLD includes } \\
\text { and/or links to } \\
\text { interactive activities, } \\
\text { in which students can } \\
\text { edit or enter data. } \\
\text { Most of these are } \\
\text { logically sequenced } \\
\text { in the CBLD, and/or } \\
\text { are well linked to } \\
\text { learning objectives. }\end{array}$ & $\begin{array}{l}\text { The CBLD includes } \\
\text { and/or links to } \\
\text { interactive activities, } \\
\text { in which students } \\
\text { can edit or enter } \\
\text { data. They are not } \\
\text { logically sequenced } \\
\text { in the CBLD, and/or } \\
\text { are not linked to } \\
\text { learning objectives. }\end{array}$ & $\begin{array}{l}\text { The CBLD } \\
\text { includes and/or } \\
\text { links to no } \\
\text { interactive } \\
\text { activities. }\end{array}$ \\
\hline $\begin{array}{l}\text { Engagement } \\
\text { (e.g. games, } \\
\text { quizzes, } \\
\text { videos, quotes, } \\
\text { random } \\
\text { names, and } \\
\text { widgets) }\end{array}$ & $\begin{array}{l}\text { The CBLD includes } \\
\text { and/or links to a } \\
\text { large variety of } \\
\text { learning tools that } \\
\text { can potentially } \\
\text { stimulate a high level } \\
\text { of learner } \\
\text { engagement. }\end{array}$ & $\begin{array}{l}\text { The CBLD includes } \\
\text { and/or links to some } \\
\text { learning tools that can } \\
\text { potentially stimulate a } \\
\text { moderate level of } \\
\text { learner engagement. }\end{array}$ & $\begin{array}{l}\text { The CBLD includes } \\
\text { and/or links to a few } \\
\text { learning tools that } \\
\text { can potentially } \\
\text { stimulate a low level } \\
\text { of learner } \\
\text { engagement. }\end{array}$ & $\begin{array}{l}\text { The CBLD } \\
\text { has/links to no } \\
\text { learning tools that } \\
\text { can potentially } \\
\text { stimulate any } \\
\text { level of learner } \\
\text { engagement. }\end{array}$ \\
\hline $\begin{array}{l}\text { Learning } \\
\text { Preferences }\end{array}$ & $\begin{array}{l}\text { The CBLD balances } \\
\text { well between the use } \\
\text { of multimodal } \\
\text { materials and tools to } \\
\text { accommodate } \\
\text { multiple learning } \\
\text { preferences. }\end{array}$ & $\begin{array}{l}\text { The CBLD balances } \\
\text { between the use of } \\
\text { multimodal materials } \\
\text { and tools to } \\
\text { accommodate most } \\
\text { learning preferences. }\end{array}$ & $\begin{array}{l}\text { The CBLD } \\
\text { minimally balances } \\
\text { between the use of } \\
\text { multimodal materials } \\
\text { and tools to } \\
\text { accommodate one } \\
\text { learning preferences. }\end{array}$ & $\begin{array}{l}\text { The CBLD shows } \\
\text { no balance } \\
\text { between the use } \\
\text { of multimodal } \\
\text { materials and } \\
\text { tools to } \\
\text { accommodate any } \\
\text { learning } \\
\text { preference. }\end{array}$ \\
\hline $\begin{array}{l}\text { Tools and } \\
\text { Media }\end{array}$ & $\begin{array}{l}\text { The CBLD takes full } \\
\text { advantage of tools } \\
\text { and media by using } \\
\text { them in a suitable } \\
\text { way to the content } \\
\text { and audience. }\end{array}$ & $\begin{array}{l}\text { The CBLD takes } \\
\text { some advantage of } \\
\text { the available tools } \\
\text { and media by using } \\
\text { them in a suitable } \\
\text { way to the content } \\
\text { and audience. }\end{array}$ & $\begin{array}{l}\text { The CBLD takes } \\
\text { limited advantage of } \\
\text { available tools and } \\
\text { media by using them } \\
\text { in a suitable way to } \\
\text { the content and } \\
\text { audience. }\end{array}$ & $\begin{array}{l}\text { The CBLD takes } \\
\text { no advantage of } \\
\text { available tools } \\
\text { and media. }\end{array}$ \\
\hline
\end{tabular}




\begin{tabular}{|l|l|l|l|l|}
\hline Links & $\begin{array}{l}\text { The CBLD links and } \\
\text { external resources } \\
\text { are clearly relevant } \\
\text { to the content. }\end{array}$ & $\begin{array}{l}\text { The CBLD links and } \\
\text { external resources are } \\
\text { relevant to the } \\
\text { content for the most } \\
\text { part. }\end{array}$ & $\begin{array}{l}\text { The CBLD links and } \\
\text { external resources } \\
\text { are minimally } \\
\text { relevant to the } \\
\text { content. }\end{array}$ & $\begin{array}{l}\text { The CBLD links } \\
\text { and external } \\
\text { resources are } \\
\text { irrelevant to } \\
\text { content. }\end{array}$ \\
\hline $\begin{array}{l}\text { Visual } \\
\text { Consistency } \\
\text { (eg. text font } \\
\text { size and colour } \\
\text { of text and } \\
\text { background })\end{array}$ & $\begin{array}{l}\text { The CBLD is } \\
\text { visually consistent } \\
\text { throughout the } \\
\text { design. }\end{array}$ & $\begin{array}{l}\text { The CBLD is visually } \\
\text { consistent in most of } \\
\text { the design. }\end{array}$ & $\begin{array}{l}\text { The CBLD is } \\
\text { visually consistent in } \\
\text { a few parts of the } \\
\text { design. }\end{array}$ & $\begin{array}{l}\text { The CBLD has no } \\
\text { visual consistency } \\
\text { throughout the } \\
\text { design. }\end{array}$ \\
\hline $\begin{array}{l}\text { Navigation } \\
\text { Flow } \\
\text { (e.g. layout, } \\
\text { site structure, } \\
\text { and page and } \\
\text { section } \\
\text { heading })\end{array}$ & $\begin{array}{l}\text { Transition between } \\
\text { all the components } \\
\text { of the CBLD is clear } \\
\text { and logical. }\end{array}$ & $\begin{array}{l}\text { Transition between } \\
\text { most of the } \\
\text { components of the } \\
\text { CBLD is clear and } \\
\text { logical. }\end{array}$ & $\begin{array}{l}\text { Transition between } \\
\text { only a few } \\
\text { components of the } \\
\text { CBLD is clear and } \\
\text { logical. }\end{array}$ & $\begin{array}{l}\text { Transition } \\
\text { between all the } \\
\text { components of the } \\
\text { CBLD is not clear } \\
\text { or logical. }\end{array}$ \\
\hline $\begin{array}{l}\text { Functionality } \\
\text { fench }\end{array}$ & $\begin{array}{l}\text { All CBLD links and } \\
\text { resources are } \\
\text { functioning well. }\end{array}$ & $\begin{array}{l}\text { Some CBLD links } \\
\text { and resources are } \\
\text { functioning well. }\end{array}$ & $\begin{array}{l}\text { A few CBLD links } \\
\text { and resources are } \\
\text { functioning well. }\end{array}$ & $\begin{array}{l}\text { No CBLD links } \\
\text { and resources are } \\
\text { functioning well. }\end{array}$ \\
\hline
\end{tabular}

Table 1. Cohen’s Kappa Coefficient for Rubric Components ( $n=31$ CBLD)

\begin{tabular}{|c|c|c|c|c|}
\hline \multirow[b]{2}{*}{ Component } & \multicolumn{3}{|c|}{ Cohen Kappa } & \multirow{2}{*}{$\begin{array}{c}\text { Average } \\
\text { Cohen Kappa }\end{array}$} \\
\hline & $\begin{array}{l}\text { Rater } 1 \text { and } \\
\text { Rater } 2\end{array}$ & $\begin{array}{c}\text { Rater } 1 \text { and } \\
\text { Rater } 3\end{array}$ & $\begin{array}{c}\text { Rater } 2 \text { and } \\
\text { Rater } 3\end{array}$ & \\
\hline 1) Purpose and Objectives & $.352 * *$ & $.683^{* *}$ & $.355^{* *}$ & .463 \\
\hline 2) Instructions and Guidelines & .161 & $.366^{*}$ & $.483 * *$ & .337 \\
\hline 3) Interaction & $.375^{*}$ & $.736 * *$ & $.381 * *$ & .497 \\
\hline 4) Learning Styles & $.401 *$ & $.533 * *$ & $.491^{* *}$ & .475 \\
\hline 5) Use of Media and Tools & .253 & $.450 * *$ & $.373^{*}$ & .359 \\
\hline 6) Links and Resources & $.496 * *$ & $.394 *$ & $.315^{*}$ & .402 \\
\hline 7) Active Learning & $.332 *$ & $.508 * *$ & $.565^{* *}$ & .468 \\
\hline 8) Engagement Tools & $.388 * *$ & $.469 * *$ & $.570 * *$ & .476 \\
\hline 9) Text: Visual Engagement & $.418^{* *}$ & $.464^{* *}$ & $.514 * *$ & .465 \\
\hline 10)Visual Consistency & $.309 *$ & $.558 * *$ & $.596^{* *}$ & .488 \\
\hline 11)Visually Appealing & $.243 *$ & $.470 * *$ & $.282 *$ & .332 \\
\hline 12)Navigation Flow & .242 & $.311^{*}$ & $.503 * *$ & .352 \\
\hline
\end{tabular}

*Significant at .01; ***Significant at .001 
Table 2. Intraclass Correlation Coefficient for Rubric Components ( $\mathrm{n}=31 \mathrm{CBLD})$

\begin{tabular}{|c|c|c|c|c|c|c|}
\hline & \multirow{4}{*}{ Component } & \multirow{4}{*}{$\begin{array}{c}\text { Intraclass Correlation } \\
\text { Coefficient (ICC) }\end{array}$} & \multicolumn{2}{|c|}{ 95\% Confidence } & \multirow{4}{*}{$\begin{array}{c}\text { F- } \\
\text { value }\end{array}$} & \multirow{4}{*}{$\begin{array}{c}p \text { - } \\
\text { value }\end{array}$} \\
\hline & & & \multicolumn{2}{|c|}{ Interval } & & \\
\hline & & & Lower & Upper & & \\
\hline & & & Band & Band & & \\
\hline 1) & Purpose and Objectives & .851 & .703 & .927 & 8.236 & .000 \\
\hline 2) & Instructions and & .838 & .709 & .916 & 6.280 & .000 \\
\hline & Guidelines & & & & & \\
\hline 3) & Interaction & .850 & .727 & .923 & 6.504 & .000 \\
\hline 4) & Learning Styles & .887 & .796 & .942 & 9.168 & .000 \\
\hline 5) & Use of Media and Tools & .811 & .660 & .902 & 5.505 & .000 \\
\hline 6) & Links and Resources & .821 & .676 & .907 & 5.600 & .000 \\
\hline 7) & Active Learning & .885 & .791 & .941 & 9.216 & .000 \\
\hline 8) & Engagement Tools & .887 & .791 & .942 & 9.707 & .000 \\
\hline 9) & Text: Visual Engagement & .895 & .799 & .947 & 11.031 & .000 \\
\hline 10) & Visual Consistency & .862 & .741 & .930 & 8.224 & .000 \\
\hline 11) & Visually Appealing & .820 & .628 & .931 & 7.166 & .000 \\
\hline 12) & Navigation Flow & .682 & .420 & .836 & 3.638 & .000 \\
\hline & Total Score & .937 & .875 & .969 & 18.909 & .000 \\
\hline
\end{tabular}

$d f 1=30 ; d f 2=60$ 
Table 3. Responses of Experts to Rubric Validation Questionnaire

\begin{tabular}{|c|c|c|c|c|c|c|c|c|c|c|c|c|c|c|c|c|}
\hline \multirow{3}{*}{ Items } & \multicolumn{4}{|c|}{ Language Clarity } & \multicolumn{4}{|c|}{ Relevance to TPCK } & \multicolumn{4}{|c|}{$\begin{array}{l}\text { Distinctiveness of } \\
\text { item levels }\end{array}$} & \multicolumn{4}{|c|}{ Importance } \\
\hline & \multicolumn{2}{|c|}{$\frac{\bar{\Xi}}{U}$} & \multicolumn{2}{|c|}{$\begin{array}{l}\tilde{\Xi} \\
\stackrel{\Xi}{U} \\
\tilde{0} \\
z\end{array}$} & \multicolumn{2}{|c|}{ 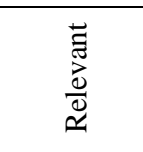 } & \multicolumn{2}{|c|}{ 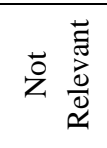 } & \multicolumn{2}{|c|}{ 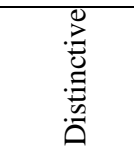 } & \multicolumn{2}{|c|}{ z。 } & \multicolumn{2}{|c|}{ 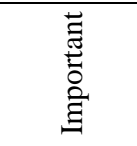 } & \multicolumn{2}{|c|}{ 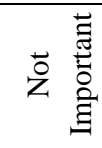 } \\
\hline & $\mathrm{n}$ & $\%$ & $\mathrm{n}$ & $\%$ & $\mathrm{n}$ & $\%$ & $\mathrm{n}$ & $\%$ & $\mathrm{n}$ & $\%$ & & & $\mathrm{n}$ & $\%$ & $\mathrm{n}$ & $\%$ \\
\hline 1. Purpose and Objectives & 11 & 85 & 2 & 15 & 9 & 69 & 4 & 31 & 11 & 85 & 2 & 15 & 13 & 100 & 0 & - \\
\hline $\begin{array}{l}\text { 2. Instructions and } \\
\text { Guidelines }\end{array}$ & 10 & 77 & 3 & 23 & 10 & 77 & 3 & 23 & 13 & 100 & 0 & - & 13 & 100 & 0 & - \\
\hline 3. Interactivity & 11 & 85 & 2 & 15 & 10 & 77 & 3 & 23 & 11 & 85 & 2 & 15 & 13 & 100 & 0 & - \\
\hline 4. Engagement & 10 & 77 & 3 & 23 & 11 & 85 & 2 & 15 & 10 & 77 & 3 & 23 & 11 & 92 & 1 & 8 \\
\hline 5. Learning styles & 11 & 85 & 2 & 15 & 11 & 85 & 2 & 15 & 11 & 85 & 2 & 15 & 10 & 77 & 3 & 23 \\
\hline 6. Tools and Media & 10 & 77 & 3 & 23 & 13 & 100 & 0 & - & 11 & 85 & 2 & 15 & 13 & 100 & 0 & - \\
\hline 7. Links & 9 & 69 & 4 & 31 & 11 & 85 & 2 & 15 & 10 & 77 & 3 & 23 & 13 & 100 & 0 & - \\
\hline 8. Visual Consistency & 12 & 92 & 1 & 8 & 8 & 62 & 5 & 38 & 13 & 100 & 0 & - & 13 & 100 & 0 & - \\
\hline 9. Navigation Flow & 8 & 67 & 4 & 33 & 9 & 75 & 3 & 25 & 12 & 100 & 0 & - & 12 & 100 & 0 & - \\
\hline 10. Functionality & 10 & 77 & 3 & 23 & 10 & 77 & 3 & 23 & 11 & 85 & 2 & 15 & 12 & 92 & 1 & 8 \\
\hline
\end{tabular}

$n=$ Number of responses/experts; $\%=$ Percentage of number of responses/experts to the total number of responses to the sub-item 
Table 4. Cohen's Kapp Coefficient for Rubric Components

\begin{tabular}{|c|c|c|c|c|c|c|c|c|}
\hline Component & $\begin{array}{c}\text { Cohen } \\
\text { Kappa } \\
\text { Phase IIII } \\
(n=46)\end{array}$ & $\begin{array}{c}p \text { - } \\
\text { value }\end{array}$ & $\begin{array}{c}\text { Cohen } \\
\text { Kappa } \\
\text { Phase V } \\
(n=144)\end{array}$ & $p$-value & $\begin{array}{c}\text { Cohen } \\
\text { Kappa } \\
\text { Phase V } \\
(n=31)\end{array}$ & $p$-value & $\begin{array}{c}\text { Cohen } \\
\text { Kappa } \\
\text { Phase VI } \\
(n=53)\end{array}$ & $p$-value \\
\hline $\begin{array}{l}\text { 1. Learning } \\
\text { Outcomes }\end{array}$ & .393 & .000 & .425 & .000 & .330 & .001 & .761 & .000 \\
\hline $\begin{array}{l}\text { 2. Instructions } \\
\text { and Guidelines }\end{array}$ & .349 & .000 & .357 & .000 & .258 & .004 & .692 & .000 \\
\hline 3. Interactivity & .208 & .000 & .309 & .000 & .075 & .496 & .741 & .000 \\
\hline 4. Engagement & .244 & .000 & .341 & .000 & .595 & .000 & .613 & .000 \\
\hline $\begin{array}{l}\text { 5. Learning } \\
\text { Preferences }\end{array}$ & .234 & .000 & .507 & .000 & .294 & .008 & .534 & .000 \\
\hline $\begin{array}{l}\text { 6. Tools and } \\
\text { Media }\end{array}$ & .182 & .001 & .120 & .001 & .308 & .003 & .887 & .000 \\
\hline 7. Links & .346 & .000 & .258 & .000 & .321 & .004 & .704 & .000 \\
\hline $\begin{array}{l}\text { 8. Visual } \\
\text { Consistency }\end{array}$ & .087 & .000 & .135 & .000 & .107 & .375 & .556 & .000 \\
\hline $\begin{array}{l}\text { 9. Navigation } \\
\text { Flow }\end{array}$ & .073 & .000 & .221 & .000 & .294 & .006 & .610 & .000 \\
\hline 10. Functionality & .497 & .000 & .354 & .000 & .330 & .008 & .542 & .000 \\
\hline
\end{tabular}

*Significant at .01; ***Significant at .001 


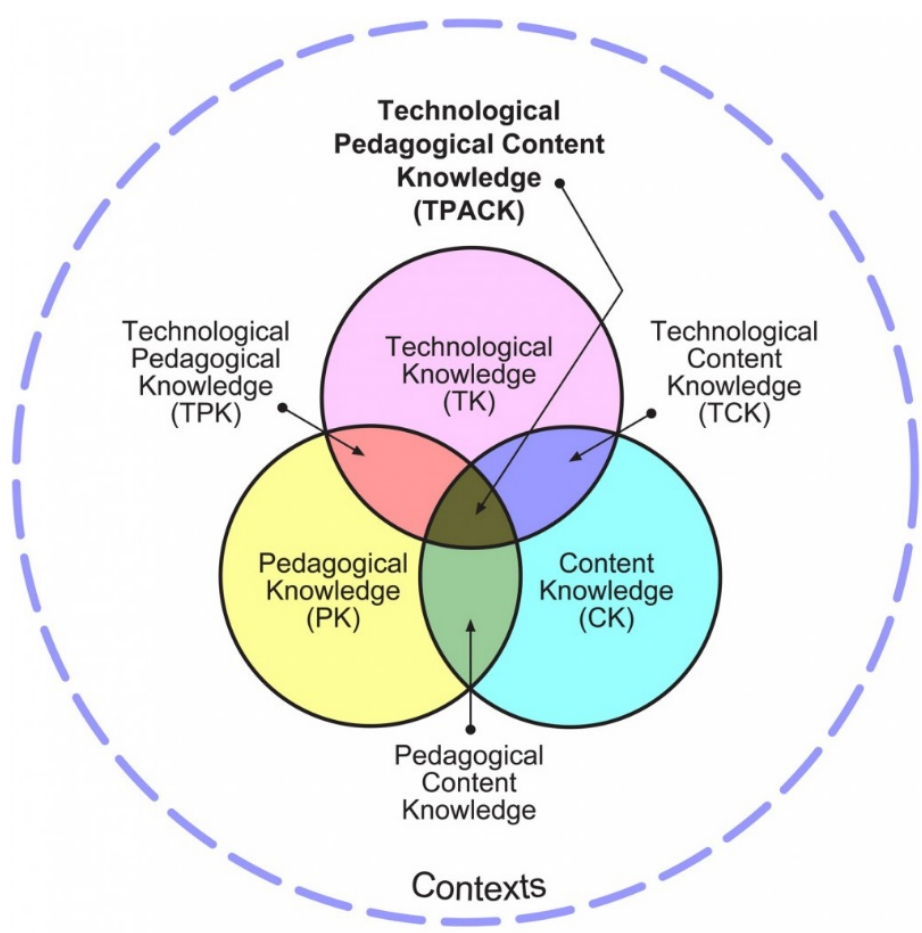

Figure 1. Technological Pedagogical Content Knowledge Reproduced by permission of the publisher, (C) 2012 by tpack.org 
Phase 1: Rubric Development

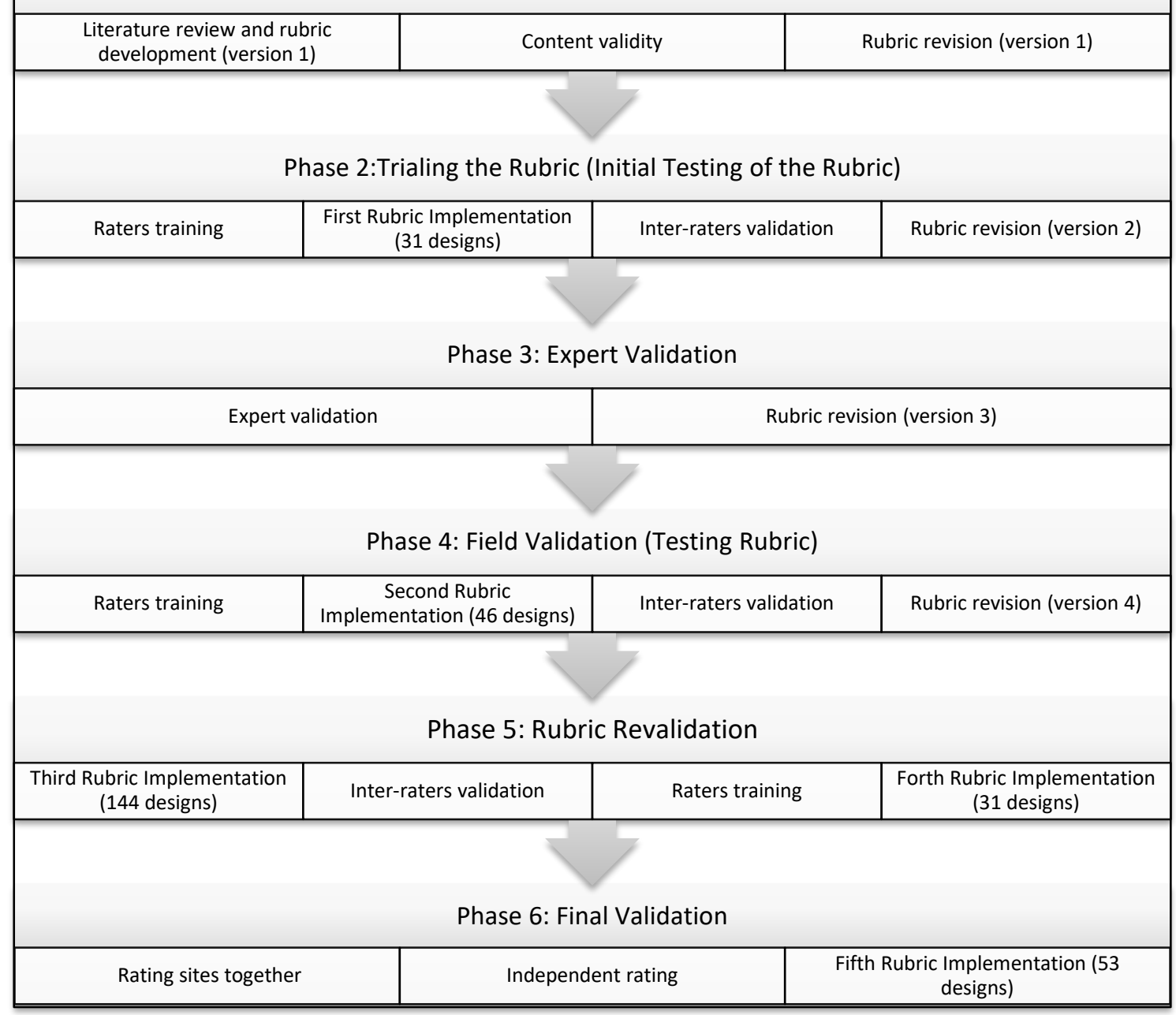

Figure 2. Rubric Design Phases 
Table 5. Rubric Item Alignment with the TPACK framework

\begin{tabular}{|c|c|c|c|}
\hline Rubric Item & Mean & Std. Deviation & How aligned are the CBLD?* \\
\hline 1. Learning Outcomes & 2.700 & 1.228 & Acceptable \\
\hline 2. Instructions \& Guidelines & 2.807 & 1.127 & Acceptable \\
\hline 3. Interactivity & 2.466 & 1.234 & Developing \\
\hline 4. Engagement & 2.708 & 1.025 & Acceptable \\
\hline 5. Learning Preferences & 3.014 & .813 & Acceptable \\
\hline 6. Tools \& Media & 2.704 & 1.015 & Acceptable \\
\hline 7. Links & 3.407 & 1.029 & Optimal \\
\hline 8. Visual Consistency & 3.405 & .787 & Optimal \\
\hline 9. Navigation Flow & 3.762 & .618 & Optimal \\
\hline 10. Functionality & 3.677 & .654 & Optimal \\
\hline
\end{tabular}

*Scores from 1-1.75 are interpreted as "Unsatisfactory"; Scores from 1.76-2.5 are interpreted as "Developing"; scores from 2.6-3.25 are interpreted as "Acceptable"; cores from 3.26-4 are interpreted as "Optimal”. 
Tables and Figures Captions:

Table 1. Cohen's Kappa Coefficient for Rubric Components ( $n=31$ CBLD)

Table 2. Intraclass Correlation Coefficient for Rubric Components ( $n=31$ CBLD)

Table 3. Responses of Experts to Rubric Validation Questionnaire

Table 4. Cohen's Kapp Coefficient for Rubric Components

Table 5. Rubric Item Alignment with the TPACK framework

Figure 1. Technological Pedagogical Content Knowledge (Koehler, 2011; Koehler \& Mishra, 2008).

Figure 2. Rubric Design Phases 